\title{
Pengaruh pendidikan kesehatan melalui short message service (sms) dan booklet tentang obesitas pada remaja overweight dan obesitas
}

The effect of health education by short message service (sms) and booklet about obesity in overweight and obese adolescent

\author{
Usi Lanita $^{1}$, Toto Sudargo ${ }^{2}$, Emy Huriyati ${ }^{2}$ \\ Minat Utama Gizi dan Kesehatan, Prodi S2 Ilmu Kesehatan Masyarakat Fakultas Kedokteran Universitas Gadjah Mada \\ 2 Departeman Gizi Kesehatan, Fakultas Kedokteran Universitas Gadjah Mada
}

\begin{abstract}
Background: Adolescent is an important period to be considered because it is a transition period between children and adult. Nutrition problem in adolescent is while decline of physical activity, teenage generally have a big appetite, hence, they often look for additional food. The majority of diet that teenage like are an energy dense, sweet, and high fat foods, which could have risk of causing overweight and obesity if consumed excessively. Therefore, one of efforts to overcome the nutrition problem is give a health education to teenage. Objective: To seek for the effect of health education by short message service (SMS) and booklet about obesity on knowledge and body mass index (BMI) in overweight and obese adolescent. Methods: This study used a quasi-experiment with pre-test and post-test design. The subject were 105 respondents of overweight and obese senior high school students. The data were analyze used a paired t-test and ANOVA with $p=0.05$ and CI=95\%. Results: Health education by SMS, booklet, and combination of SMS and booklet had a significant effect statistically $(p<0.05)$ on knowledge in overweight and obese adolescent. Combination of SMS and booklet had a significant effect statistically on BMI. The result of ANOVA in knowledge variable showed that combination of SMS and booklet group is more effective than other groups. Whereas health education of BMI variable by SMS, booklet, and combination of SMS and booklet were not effective ( $p>0.05)$ to reduce BMI in overweight and obese adolescent. Conclusion: Health education by SMS, booklet, and combination of SMS and booklet have an effect on increasing the knowledge in overweight and obese adolescent, whereas on BMI, only SMS and booklet have an effect on reducing BMI.
\end{abstract}

KEY WORDS: body mass index (BMI); booklet; knowledge; obesity; short message service (sms)

\begin{abstract}
ABSTRAK
Latar belakang: Masa remaja merupakan masa transisi antara anak-anak dan dewasa yang sangat penting untuk diperhatikan. Masalah gizi pada remaja seiring dengan menurunnya aktivitas fisik, remaja pada umumnya mempunyai selera makan yang lebih besar sehingga sering mencari makanan tambahan di luar waktu makan berupa makanan padat energi, manis, dan tinggi lemak yang berisiko menyebabkan kegemukan dan obesitas. Oleh karena itu, salah satu upaya untuk penanggulangan masalah gizi tersebut melalui pemberian pendidikan kesehatan kepada remaja. Tujuan: Mengetahui pengaruh pendidikan kesehatan melalui short message service (SMS) dan booklet tentang obesitas terhadap pengetahuan dan indeks massa tubuh (IMT) remaja overweight dan obesitas. Metode: Penelitian eksperimen semu dengan rancangan pre-test dan post-test. Perlakuan yang diberikan yaitu pendidikan kesehatan berupa SMS (kelompok I); booklet (kelompok II); dan perpaduan SMS plus booklet (kelompok III). Subjek penelitian adalah remaja SMA yang mengalami overweight dan obesitas sebanyak 105 responden. Analisis menggunakan uji paired t-test dan uji ANOVA dengan $\mathrm{p}=0,05$ dan CI=95\%. Hasil: Pendidikan kesehatan melalui SMS, booklet, dan perpaduan SMS plus booklet secara statistik pengaruhnya bermakna $(\mathrm{p}<0,05)$ terhadap pengetahuan remaja overweight dan obesitas. Perpaduan SMS plus booklet secara statistik berpengaruh terhadap IMT $(p<0,05)$ dan sebaliknya dengan kelompok SMS dan kelompok booklet $(\mathrm{p}>0,05)$. Kelompok perpaduan SMS plus booklet lebih berpengaruh (efektif) terhadap peningkatan pengetahuan dibandingkan kedua kelompok lainnya. Sementara pendidikan kesehatan melalui SMS, booklet, dan perpaduan SMS plus booklet tidak efektif ( $>00,05$ ) untuk menurunkan IMT pada remaja overweight dan obesitas. Simpulan: Pendidikan kesehatan menggunakan SMS, booklet, dan perpaduan SMS plus booklet berpengaruh terhadap peningkatan pengetahuan remaja overweight dan obesitas. Namun, hanya media SMS plus booklet yang berpengaruh dalam menurunkan IMT.
\end{abstract}

KATA KUNCI: indeks massa tubuh (IMT); booklet; pengetahuan; obesitas; short message service (sms) 


\section{PENDAHULUAN}

Dahulu badan gemuk dianggap sebagai simbol kemakmuran karena umumnya masalah kegemukan banyak dijumpai di negara kaya seperti Amerika Serikat dan negara-negara Eropa yang tergolong makmur. Pendapat tersebut sekarang sudah tidak tepat lagi. Negara-negara yang dulu miskin dan sedang berkembang seperti China, beberapa negara di Afrika, India, dan Indonesia, selain banyak ditemukan anak dan dewasa kurus serta pendek akibat kekurangan gizi, juga mulai sering dijumpai kegemukan karena kelebihan gizi (1). Prevalensi obesitas pada anak usia 2 sampai 19 tahun di Amerika Serikat dalam 3 dekade terakhir meningkat dari 27,5\% menjadi 31,1\% (2). Prevalensi obesitas pada anak usia 6-12 tahun di Bangkok meningkat dari 12,2\% menjadi 15,6\% dan angka prevalensi di Jepang pada anak 6-14 tahun dari 5\% menjadi 10\% (3). Hasil Riskesdas tahun 2013 menunjukkan bahwa prevalensi overweight dan obesitas di Indonesia pada usia 18 tahun ke atas secara nasional sebesar $13,5 \%$ dan $15,4 \%$. Sementara prevalensi kegemukan pada remaja usia 16 - 18 tahun sebanyak 7,3\% yang terdiri dari 5,7\% overweight dan 1,6\% obesitas. Provinsi Daerah Istimewa Yogyakarta (DIY) merupakan salah satu provinsi dengan prevalensi obesitas di atas prevalensi nasional (4). Hasil penelitian yang dilakukan pada anak sekolah tahun 2004 di Yogyakarta menemukan kasus obesitas sebesar 7,9\% pada remaja di kota dan 2\% di desa (5).

Masa remaja sangat penting diperhatikan karena merupakan masa transisi antara anak-anak dan dewasa. Masalah gizi remaja yaitu seiring dengan menurunnya aktivitas fisik, remaja umumya mempunyai nafsu makan lebih besar sehingga sering mencari makanan tambahan, misalnya jajan di luar waktu makan. Remaja menyukai makanan padat energi, manis, dan berlemak, padahal makanan tersebut bila sering dikonsumsi berisiko menyebabkan kegemukan. Obesitas erat kaitannya dengan beberapa penyakit yang serius seperti tekanan darah tinggi, penyakit jantung koroner, diabetes mellitus, dan penyakit saluran napas (6).

Penelitian pada mahasiswi akademi kebidanan tentang promosi kesehatan untuk penanggulangan overweight dan obesitas melalui transparansi dan booklet berhasil meningkatkan pengetahuan, sikap, dan perilaku kelompok perlakuan (7). Sama seperti hasil penelitian di Korea yang memanfaatkan fitur pesan layanan singkat pada ponsel untuk memodifikasi perilaku dalam pengendalian berat badan menunjukkan bahwa mayoritas peserta merasa puas dengan pesan SMS (8). Namun, penelitian tersebut belum menyimpulkan media pendidikan kesehatan yang tepat dan efektif dalam modifikasi perilaku untuk mengatasi masalah gizi terutama masalah obesitas pada remaja yang sebagaimana diketahui bahwa masalah tersebut akan menimbulkan dampak berbahaya terhadap kesehatan di masa depan. Oleh karena itu, peneliti tertarik untuk melakukan penelitian dengan tujuan mengetahui pengaruh pendidikan kesehatan tentang obesitas melalui short message service (SMS) dan booklet terhadap pengetahuan dan indeks massa tubuh (IMT) remaja overweight dan obesitas di SMA Kota Yogyakarta.

\section{BAHAN DAN METODE}

Penelitian analitik dengan jenis penelitian eksperimen semu dan rancangan penelitian pre-test dan post-test. Pada kelompok intervensi dilakukan pre-test dan post-test terhadap pengetahuan dan indeks massa tubuh (IMT) masing-masing kelompok. Perlakuan yang diberikan dibagi menjadi tiga kelompok yaitu pemberian intervensi melalui SMS (X1); pemberian intervensi melalui booklet (X2); dan pemberian intervensi melalui perpaduan SMS plus booklet (X3). Penelitian dilaksanakan pada bulan Mei-Juli 2014 di tiga SMA Kota Yogyakarta yaitu SMA Negeri 2, SMA Negeri 6, dan SMA Negeri 10. Populasi adalah seluruh pelajar SMA di Kota Yogyakarta sedangkan sampel dipilih berdasarkan kriteria inklusi dan eksklusi. Kriteria inklusi yaitu siswa yang mengalami overweight dan obesitas; memiliki telepon seluler walaupun tidak dibawa ke sekolah; dan bersedia mengikuti penelitian (informed consent) sedangkan kriteria ekslusinya yaitu menjalani program fitnes atau atlet dan menjalani diet khusus atau konsumsi obat pelangsing.

Hasil perhitungan dengan rumus besar sampel minimal berdasarkan analitis-numerik berpasangan diperoleh sebesar 35 responden untuk setiap kelompok perlakuan sehingga total sampel sebesar 105 responden. 
Cara pengambilan sampel dilakukan dengan menggunakan teknik pengambilan sampel acak sederhana (simple random sampling) yaitu setelah dilakukan skrining status gizi pada siswa-siswi di tiga SMA tersebut kemudian dilakukan pemilihan sampel secara acak sederhana terhadap siswa-siswi yang mempunyai status gizi overweight maupun obesitas sebanyak 35 responden pada masing-masing sekolah. Remaja dikategorikan overweight jika pengukuran IMT berdasarkan umur (IMT/U) berada pada $\geq$ persentil ke-85 sedangkan obesitas jika berada pada $\geq$ persentil ke-95.

Variabel bebas pada penelitian ini yaitu pendidikan kesehatan melalui sms dan booklet, variabel terikat yaitu pengetahuan dan IMT, serta variabel antara adalah asupan energi dan aktivitas fisik. Layanan SMS dikirim melalui handphone dengan pesan yang dikirim maksimal berisi 160 karakter dan proses pengiriman SMS dilakukan selama 2 bulan dengan frekuensi 2 hari sekali. Isi pesan yang dikirim dibuat oleh peneliti dengan memodifikasi materi SMS pada penelitian Joo dan Kim (8) sedangkan isi booklet dibuat oleh peneliti dari hasil modifikasi materi booklet tentang obesitas pada penelitian sebelumnya yang dilakukan oleh Saragih (7). Booklet berisikan tentang definisi obesitas dan pengukurannya, penyebab obesitas, dampak obesitas, dan tips penanggulangan obesitas. Booklet diberikan hanya sekali yaitu setelah dilakukan pre-test terhadap subjek.

Variabel pengetahuan diukur dengan menggunakan kuesioner pengetahuan tentang obesitas dan variabel IMT diukur menggunakan timbangan (berat badan) dan microtoise (tinggi badan). Asupan energi diketahui dengan recall 3x24 jam yang dilakukan pada 2 hari sekolah dan 1 hari libur. Sementara aktivitas fisik diukur menggunakan
International Physical Activity Questionnaire (IPAQ) yang sudah dimodifikasi oleh penelitian (9). Kuesioner pengetahuan berbentuk pertanyaan tertutup sebanyak 20 pertanyaan tentang obesitas (7). Penilaian pengetahuan dilakukan dengan memberi skor berdasarkan jawaban, jika salah diberi skor 0 dan benar diberi skor 1 sehingga skor total minimum 0 dan maksimum adalah 17 . Uji validitas dan reliabilitas menunjukkan bahwa pertanyaan pada kuesioner dan booklet yang digunakan sebagai instrumen penelitian sudah valid dan reliabel.

Analisis data dengan paired t-test untuk melihat perubahan pre-test dan post-test pada masing-masing kelompok perlakuan, kemudian dilakukan juga analysis of variance (ANOVA) untuk melihat perbedaan antarkelompok perlakuan yang dilanjutkan dengan uji multiple comparison (MCA). Selain itu, dilakukan juga uji korelasi untuk melihat hubungan asupan energi dan aktivitas fisik terhadap indeks massa tubuh (IMT). Penelitian ini telah mendapat keterangan kelayakan etik dari Komisi Etik Penelitian Kedokteran dan Kesehatan Masyarakat Fakultas Kedokteran Universitas Gadjah Mada Yogyakarta dengan nomor KE/FK/648/EC.

\section{HASIL}

\section{Karakteristik subjek penelitian}

Hasil uji homogenitasnya pada variabelvariabel penelitian seperti pada Tabel $\mathbf{1}$ menunjukkan bahwa karakteristik subjek pada ketiga kelompok perlakuan adalah homogen atau sama $(p>0,05)$. Hal ini menunjukkan bahwa ketiga kelompok perlakuan mempunyai karakteristik yang sama atau tidak ada

Tabel 1. Karakteristik subjek penelitian

\begin{tabular}{lrrrrrrr}
\hline \multirow{2}{*}{ Karakteristik } & \multicolumn{7}{c}{ Kelompok perlakuan } \\
\cline { 2 - 8 } & \multicolumn{2}{c}{ SMS $^{\text {a }}$} & \multicolumn{7}{c}{ Booklet } & \multicolumn{3}{c}{ SMS + Booklet } & p \\
\cline { 2 - 8 } & Rerata & SD $^{\mathbf{b}}$ & Rerata & SD & Rerata & \multicolumn{1}{c}{ SD } \\
\hline Umur (tahun) & 16,14 & 0,77 & 16,26 & 0,70 & 16,28 & 0,66 & 0,67 \\
Berat badan (kg) & 79,07 & 12,84 & 77,02 & 12,37 & 77,92 & 10,38 & 0,77 \\
Tinggi badan (cm) & 164,25 & 7,65 & 161,90 & 9,94 & 164,62 & 8,61 & 0,37 \\
Pengetahuan (skor) & 14,34 & 2,04 & 13,46 & 2,18 & 14,60 & 2,17 & 0,07 \\
IMT $^{*}\left(\mathrm{~kg} / \mathrm{m}^{2}\right.$ ) & 29,15 & 3,03 & 27,30 & 2,58 & 28,72 & 2,67 & 0,11 \\
Asupan energi (kkal) & 2536,71 & 257,31 & 2426,58 & 298,95 & 2550,80 & 233,71 & 0,10 \\
Aktifitas fisik (Mets) & 1338,35 & 283,22 & 1468,95 & 271,46 & 1385,95 & 225,54 & 0,11 \\
\hline
\end{tabular}

${ }^{\mathrm{a} S M S}=$ short message service $;{ }^{\mathrm{b}} \mathrm{SD}=$ standar deviasi; ${ }^{\mathrm{c}} \mathrm{IMT}=$ indeks massa tubuh 
Tabel 2. Perbedaan nilai rerata pengetahuan pre-test dan post-test masing-masing kelompok perlakuan

\begin{tabular}{llrcccc}
\hline Kelompok perlakuan & Rerata & SD $^{\mathbf{a}}$ & $\mathbf{p}^{\mathbf{b}}$ & Beda rerata & $\mathbf{9 5 \%}$ CI \\
SMS $^{\mathrm{c}}$ & Pre-test & 14,34 & 2,04 & $0,01^{*}$ & 1,88 & $1,29-2,47$ \\
\multirow{3}{*}{ Booklet } & Post-test & 16,23 & 1,21 & & & \\
& Pre-test & 13,46 & 2,18 & $0,01^{*}$ & 1,00 & $0,49-1,50$ \\
\multirow{3}{*}{ SMS + booklet } & Post-test & 14,46 & 1,77 & & & \\
& Pre-test & 14,60 & 2,17 & $0,01 *$ & 2,11 & $1,36-22,86$ \\
& Post-test & 16,71 & 0,51 & & & \\
\hline
\end{tabular}

*Signifikansi $(\mathrm{p}<0,05) ;{ }^{\mathrm{a}} \mathrm{SD}=$ standar deviasi; ${ }^{\mathrm{b}}$ paired $t$-test ' ${ }^{\mathrm{c}} \mathrm{SMS}=$ short message service

Tabel 3. Perbedaan nilai rerata IMT pre-test dan post-test antarkelompok perlakuan

\begin{tabular}{llrlccc}
\hline Kelompok perlakuan & Rerata & SD $^{1}$ & $\mathbf{p}^{2}$ & Beda rerata & $\mathbf{9 5 \%}$ CI \\
SMS $^{3}$ & Pre-test & 28,15 & 3,05 & 0,56 & $-0,07$ & $-0,32--0,17$ \\
\multirow{5}{*}{ Booklet } & Post-test & 28,08 & 3,04 & & & \\
& Pre-test & 27,31 & 2,58 & 0,39 & $-0,06$ & $0,19--0,07$ \\
\multirow{3}{*}{ SMS + booklet } & Post-test & 27,25 & 2,46 & & & \\
& Pre-test & 28,71 & 2,67 & $0,04^{*}$ & $-0,09$ & $-0,18--0,01$ \\
& Post-test & 28,62 & 2,73 & & & \\
\hline
\end{tabular}

*Signifikansi $(\mathrm{p}<0,05) ;{ }^{\mathrm{a}} \mathrm{SD}=$ standar deviasi; ${ }^{\mathrm{b}}$ paired $\mathrm{t}$-test $;{ }^{\mathrm{c} S M S}=$ short message service

perbedaan sebelum dilakukan intervensi. Karakteristik awal yang sama atau seimbang pada kelompok yang diteliti merupakan syarat yang harus dipenuhi untuk penelitian eksperimen. Karakteristik yang homogen ini juga sesuai dengan dengan penelitian sebelumnya yang menyatakan bahwa sebelum melakukan penelitian eksperimen, masing-masing kelompok penelitian harus setara atau sebanding (10-12).

\section{Pengaruh pendidikan kesehatan terhadap pengetahuan}

Hasil analisis paired t-test menunjukkan bahwa rerata pengetahuan remaja overweight dan obesitas mengalami peningkatan signifikan $(p<0,05)$ setelah diberikan intervensi pendidikan kesehatan tentang obesitas, baik itu kelompok SMS, kelompok booklet maupun kelompok perpaduan SMS plus booklet (Tabel 2). Hasil analisis ANOVA menunjukkan terdapat perbedaan rerata peningkatan pengetahuan yang signifikan antar ketiga kelompok perlakuan $(p=0,02)$. Dengan demikian, dapat dikatakan bahwa ada perbedaan efektivitas media antara kelompok SMS, kelompok booklet, dan kelompok perpaduan SMS plus booklet. Oleh karena itu, dilanjutkan dengan uji MCA untuk melihat kelompok mana yang paling efektif atau tertinggi pengaruhnya terhadap peningkatan pengetahuan subjek. Hasil uji MCA dapat disimpulkan bahwa pada penelitian ini media pendidikan kesehatan melalui perpaduan SMS plus booklet merupakan media yang paling efektif atau terbaik dalam meningkatkan pengetahuan pada remaja overweight dan obesitas.

\section{Pengaruh pendidikan kesehatan terhadap IMT}

Pengaruh pendidikan kesehatan terhadap IMT remaja overweight dan obese berdasarkan hasil analisis paired t-test menunjukkan bahwa rerata nilai IMT menurun setelah dilakukan intervensi pendidikan kesehatan tentang obesitas. Penurunan rerata IMT pada kelompok SMS maupun kelompok booklet secara statistik tidak signifikan ( $\mathrm{p}>0,05)$ sedangkan pada kelompok perpaduan SMS plus booklet terjadi penurunan secara signifikan (Tabel 3). Hasil analisis ANOVA juga menunjukkan bahwa tidak ada perbedaan selisih rerata IMT antar ketiga kelompok perlakuan $(p=0,95)$. Dengan demikian, dapat disimpulkan bahwa pendidikan kesehatan melalui ketiga media tersebut tidak ada yang lebih efektif untuk menurunkan IMT remaja overweight dan obesitas. 


\section{Hubungan asupan energi dan aktivitas fisik terhadap IMT}

Hasil analisis korelasi antara asupan energi dengan IMT menunjukkan bahwa hubungan yang sangat lemah $(\mathrm{r}=0,12)$ dan secara statistik tidak signifikan $(\mathrm{p}=0,21)$. Namun, apabila dilihat dari arah hubungannya antara asupan energi dan IMT mempunyai hubungan positif. Artinya, jika terjadi peningkatan asupan energi maka IMT juga akan mengalami peningkatan. Berbeda dengan aktivitas fisik dan IMT yang menunjukkan arah hubungan negatif, yaitu jika aktivitas fisik menurun maka IMT akan meningkat, begitupun sebaliknya. Kekuatan hubungan antara aktivitas fisik dengan IMT pada penelitian ini juga sangat lemah $(\mathrm{r}=-0,01)$ dan tidak signifikan $(\mathrm{p}=0,90)$. Berdasarkan analisis korelasi tersebut, maka dapat disimpulkan bahwa pada penelitian ini hubungan antara asupan energi dan aktivitas fisik terhadap IMT tidak bermakna.

Lebih lanjut, selain dilakukan analisis korelasi dilakukan juga analisis paired t-test dan analisis ANOVA pada variabel asupan energi dan aktivitas fisik. Hasil analisis menunjukkan bahwa pemberian pendidikan kesehatan melalui SMS, booklet, dan perpaduan SMS plus booklet pada penelitian ini tidak memberikan pengaruh yang signifikan ( $p>0,05)$ terhadap asupan energi dan aktivitas fisik.

\section{BAHASAN}

\section{Pengaruh pendidikan kesehatan terhadap pengeta- huan}

Berdasarkan hasil penelitian diketahui bahwa pendidikan kesehatan memberikan pengaruh signifikan terhadap peningkatan pengetahuan pada masingmasing kelompok perlakuan. Selanjutnya, setelah dilakukan perbandingan antar ketiga kelompok perlakuan menunjukkan bahwa secara statistik ada perbedaan pengaruh media terhadap pengetahuan pada remaja overweight dan obesitas. Intervensi menggunakan media SMS mampu meningkatkan pengetahuan remaja tentang obesitas. Sejalan dengan hasil penelitian sebelumnya (13) bahwa telepon seluler merupakan salah satu jenis teknologi komunikasi yang efektif dan layak untuk memberikan informasi melalui pengiriman isi SMS sebagai pengingat (reminder) dalam upaya promosi kesehatan masyarakat. Penelitian di Iran (43) menunjukkan efektivitas intervensi menggunakan SMS melalui telepon seluler terhadap pengetahuan dalam pengelolaan diabetes melitus tipe 2 . Adanya peningkatan pengetahuan bisa disebabkan karena kelebihan dari media SMS diantaranya pesan dapat terikirim dalam waktu yang cepat, dibaca pada waktu yang sesuai, adanya komunikasi dua arah, dan SMS lebih murah dibandingkan media cetak lainnya (15).

Pendidikan kesehatan melalui booklet pada penelitian ini juga mampu meningkatkan pengetahuan remaja overweight dan obesitas. Hasil penelitian pada remaja di Tasikmalaya (16) menunjukkan bahwa pengetahuan pada kelompok perlakuan yang mendapatkan pendidikan kesehatan melalui booklet mengalami peningkatan. Penelitian yang dilakukan pada perawat di rumah sakit juga menunjukkan hasil bahwa ada perbedaan yang signifikan peningkatan pengetahuan sebelum dan sesudah pemberian booklet (17). Disebutkan bahwa pendidikan kesehatan menggunakan media booklet berperan dalam meningkatkan pengetahuan, media ini dapat mengefektifkan proses penyampaian isi materi pengajaran yang diberikan (18).

Intervensi pendidikan kesehatan melalui SMS plus booklet pada penelitian ini juga menunjukkan bahwa perpaduan dua media berpengaruh dalam meningkatkan pengetahuan remaja tentang obesitas. Sebagaimana disebutkan bahwa penggabungan beberapa media dapat meningkatkan pengetahuan seseorang. Perpaduan media SMS plus booklet akan dengan mudah dipelajari dan dipahami, ini disebabkan mereka bisa membaca dan melihat isi materi yang ada di dalam booklet, juga mendapatkan informasi tambahan melalui SMS yang dikirimkan kepada mereka setiap dua hari sekali. Menurut penelitian sebelumnya juga diketahui adanya pengaruh pendidikan kesehatan dengan metode ceramah disertai dengan booklet terhadap peningkatan pengetahuan yaitu sebelum intervensi sebesar $26,67 \%$ meningkat menjadi 90\% setelah intervensi (19).

Hasil analisis juga menunjukkan bahwa kelompok perpaduan SMS plus booklet lebih efektif meningkatkan pengetahuan dibandingkan kelompok SMS dan kelompok booklet. Media SMS plus booklet yang efektif bisa 
disebabkan oleh adanya pemberian materi tentang obesitas secara bersamaan melalui kombinasi media yaitu media cetak dan media elektronik sehingga lebih menarik dan mudah untuk dibaca dan dipahami. Sejalan dengan penelitian yang dilakukan di Kota Banda Aceh tentang kesiapsiagaan bencana alam, hasil penelitiannya menunjukkan bahwa promosi kesehatan dengan menggunakan layanan pesan pendek dan leaflet efektif untuk meningkatkan pengetahuan pelajar SMP (20).

\section{Pengaruh pendidikan kesehatan terhadap IMT}

Hasil penelitian pada ketiga kelompok perlakuan menunjukkan bahwa rerata IMT pada masing-masing kelompok mengalami penurunan setelah diberikan intervensi, meskipun hasil perbandingan antar ketiga kelompok tidak menunjukkan adanya perbedaan yang signifikan. Hasil berbeda ditunjukkan oleh penelitian di Korea (8) tentang program penurunan berat badan melalui layanan pesan singkat telepon seluler untuk modifikasi perilaku yang dilakukan selama 12 minggu menunjukkan bahwa pasca-intervensi rerata lingkar pinggang mengalami penurunan sebesar 4,3 $\mathrm{cm}$ dan IMT sebesar $0,6 \mathrm{~kg} / \mathrm{m}^{2}$. Sebagian subjek merasa puas dengan pesan yang dikirimkan dan SMS mungkin merupakan metode yang efektif dalam modifikasi perilaku untuk pengendalian berat badan. Kemungkinan perbedaan hasil penelitian ini dengan penelitian di Korea (8) tersebut bisa disebabkan oleh adanya perbedaan lama waktu penelitian, sebagaimana diketahui bahwa pada penelitian ini hanya dilakukan selama 8 minggu sedangkan pada penelitian tersebut dilakukan selama 12 minggu. Demikian juga dengan remaja overweight dan obese pada kelompok yang mendapatkan pendidikan kesehatan melalui booklet, tidak menunjukkan penurunan rerata IMT. Hal ini mungkin disebabkan frekuensi pemberian booklet pada penelitian ini hanya diberikan satu kali sehingga tidak memberikan efek yang maksimal. Selain itu mungkin juga disebabkan karena media booklet mempunyai kelemahan, diantaranya yaitu sulit menampilkan gerak, biaya cetakan mahal bila ingin menampilkan ilustrasi, foto berwarna, proses pencetakan memakan waktu lama, dan jika tidak dirawat dengan baik cepat rusak atau hilang (18).

Namun demikian, hasil penelitian ini menunjukkan pendidikan kesehatan melalui perpaduan SMS plus booklet berpengaruh terhadap penurunan IMT pada remaja overweight dan obesitas. Sejalan dengan penelitian yang dilakukan pada mahasiswi tentang promosi kesehatan untuk penanggulangan overweight dan obesitas, penelitian tersebut membuktikan adanya penurunan status obesitas menjadi overweight $(\mathrm{p}=0,04)$ pada kelompok perlakuan pada saat pre-test dibandingkan dengan post-tes (7). Lebih lanjut, penelitian tersebut menyatakan bahwa pendidikan kesehatan menggunakan booklet yang dikombinasikan dengan media lain dapat menurunkan berat badan remaja yang mengalami kegemukan, ini bisa disebabkan media tersebut mampu meningkatkan pengetahuan remaja tentang obesitas sehingga secara tidak langsung akan mempengaruhi sikap dan perilaku terhadap pengontrolan berat badan.

Setelah dilakukan perbandingan antar ketiga kelompok media pendidikan kesehatan baik itu melalui SMS, booklet maupun perpaduan SMS plus booklet ternyata tidak ada yang lebih efektif dalam menurunkan IMT. Hal ini terjadi kemungkinan karena walaupun pengetahuan mengalami peningkatan, tetapi para remaja tidak mengubah perilakunya terutama dalam pola konsumsi atau kebiasaan makan dan aktivitas fisik sehingga tidak memberikan efek dalam menurunkan berat badan. Selain itu, sebagaimana kita ketahui bahwa dalam menurunkan berat badan memerlukan waktu yang relatif lama dan memerlukan motivasi yang kuat. Pada penelitian ini, pendidikan kesehatan hanya diberikan melalui media cetak dan elektronik selama dua bulan yang bisa dikategorikan sebagai upaya preventif dan promotif serta tidak adanya perlakuan secara langsung misalnya berupa pemberian makanan ataupun suplemen tertentu sebagai upaya kuratif sehingga tidak ada efek langsung dalam menurunkan IMT pada remaja yang mengalami overweight dan obesitas.

\section{Hubungan asupan energi dan aktivitas fisik terhadap overweight dan obesitas}

Hasil analisis korelasi menunjukkan hubungan yang tidak signifikan antara asupan energi dan aktivitas fisik terhadap kejadian overweight dan obesitas berdasarkan IMT. Arah hubungan antara asupan energi dengan IMT adalah positif yaitu apabila terjadi peningkatan asupan energi maka nilai IMT juga akan meningkat. Sebaliknya 
dengan arah hubungan antara aktivitas fisik dengan IMT adalah negatif yang berarti bahwa apabila aktivitas fisik menurun maka nilai IMT akan meningkat. Hasil ini didukung oleh penelitian sebelumnya di Amerika Serikat bahwa terjadinya peningkatan persentase ukuran porsi dan asupan energi pada makanan cepat saji dan makanan manis sejalan dengan meningkatnya berat badan (obesitas) anak dan remaja (21).

Lebih lanjut, pemberian pendidikan kesehatan melalui SMS, booklet, dan perpaduan SMS plus booklet pada penelitian ini tidak memberikan pengaruh yang signifikan terhadap asupan energi. Asupan energi tidak mengalami penurunan baik itu pada masing-masing kelompok maupun setelah dilakukan perbandingan antar kelompok. Berbeda dengan pernyataan yang menyebutkan bahwa adanya penurunan asupan energi dibandingan dengan kebutuhan kemungkinan disebabkan adanya peningkatan pengetahuan responden setelah mendapatkan pendidikan kesehatan melalui booklet. Hal tersebut terjadi karena pendidikan kesehatan merupakan suatu usaha untuk mengubah perilaku seseorang yang dilakukan dengan pendekatan edukatif bertujuan untuk menumbuhkan sikap positif individu maupun masyarakat terhadap asupan gizi yang akan mempengaruhi kebiasaan makan sehingga tercapai perbaikan gizi (22). Faktor lain yang mungkin menyebabkan tidak adanya pengaruh pendidikan kesehatan terhadap asupan energi adalah karena adanya keterbatasan penelitian pada metode recall 24 jam yang sangat bergantung pada daya ingat, baik dari identifikasi makanan yang dikonsumsi maupun ukuran atau porsinya. Beberapa penelitian membuktikan bahwa konsumsi makanan yang tidak dilaporkan dengan benar oleh $20-25 \%$ subjek penelitian terutama subjek wanita, individu yang mengalami overweight, dan individu yang sensitif terhadap masalah berat badan.

Demikian juga dengan aktivitas fisik yang tidak memberikan pengaruh yang signifikan $(\mathrm{p}>0,05)$ setelah diberikan pendidikan kesehatan melalui media SMS, booklet maupun perpaduan SMS plus booklet. Tidak adanya pengaruhnya tersebut dapat disebabkan oleh berbagai faktor, seperti yang dikemukan dalam penelitian sebelumnya (23) bahwa berbagai faktor yang dapat mempengaruhi aktivitas fisik remaja diantaranya dukungan keluarga dan teman. Sementara pada penelitian ini, intervensi yang diberikan berupa pendidikan kesehatan yang hanya diberikan kepada responden saja atau dengan kata lain tidak ada intervensi terhadap keluarga atau teman mereka sebagai kelompok pendukung. Selain itu, mungkin juga bisa disebabkan oleh kebiasaan remaja yang jarang berolahraga dan terbiasa menggunakan motor, mobil atau bis sebagai alat transportasi. Arah hubungan antara aktivitas fisik dengan IMT adalah negatif, artinya bahwa apabila aktivitas fisik menurun maka IMT akan meningkat, begitupun sebaliknya bila aktivitas meningkat maka IMT akan mengalami penurunan. Adanya hubungan negatif antara aktivitas fisik dengan IMT ini menunjukkan bahwa orang yang overweight atau obesitas mempunyai aktivitas kurang dibandingkan dengan orang yang ramping atau normal.

Aktivitas fisik remaja overweight dan obesitas pada penelitian ini diketahui termasuk dalam kategori ringan. Hasil penelitian ini sejalan dengan data Riskesdas bahwa sebagian besar penduduk remaja di Indonesia memiliki aktivitas fisik pada kategori ringan. Studi yang dilakukan di Belanda menyatakan remaja overweight memiliki aktivitas fisik ringan dan masalah psikososial terkait dengan aktivitas fisik dibandingkan dengan remaja yang memiliki status berat badan normal (23). Selain itu, berdasarkan hasil penelitian di Amerika Serikat (24) memperlihatkan bahwa peningkatan aktivitas fisik mampu menurunkan status obesitas sebanyak $0,06 \mathrm{~kg} /$ $\mathrm{m}^{2}$ untuk wanita dan $0,22 \mathrm{~kg} / \mathrm{m}^{2}$ untuk laki-laki. Setiap peningkatan satu jam aktivitas menonton televisi atau video atau bermain game (play station atau game komputer) memberikan efek peningkatan berat badan sebesar $0,05 \mathrm{~kg} / \mathrm{m}^{2}$ khususnya bagi wanita.

Bukti-bukti menunjukkan bahwa latihan intensitas tinggi memiliki potensi untuk menjadi sarana yang efektif dan ekonomis dalam menggurangi massa lemak tubuh pada individu yang mengalami overweight dan obesitas (25). Oleh sebab itu, remaja disarankan untuk melakukan latihan intensitas tinggi (olahraga) dan melakukan aktivitas fisik yang bermanfaat dan menyehatkan, seperti membereskan kamar tidurnya, berkebun, berjalan agak jauh dari tempat parkir, menyapu atau mengepel sedangkan olahraga yang menyehatkan bagi remaja contohnya bola kaki, bola basket, bola voli, bulu tangkis, 
bersepeda, jogging, dan skipping (26). Selanjutnya, upaya untuk meningkatkan aktivitas fisik di kalangan remaja adalah dilakukan promosi sikap positif terhadap aktivitas fisik itu sendiri dan perlu dorongan dari anggota keluarga agar mendukung upaya remaja untuk menjadi lebih aktif (27).

Dengan demikian, dapat disimpulkan bahwa media pendidikan kesehatan melalui perpaduan SMS plus booklet merupakan media yang paling efektif dalam meningkatkan pengetahuan pada remaja overweight dan obesitas. Namun, pendidikan kesehatan melalui ketiga media tersebut tidak ada yang lebih efektif untuk menurunkan nilai IMT remaja overweight dan obesitas. Hal ini menunjukkan bahwa media short message service (SMS) dan booklet kurang tepat untuk digunakan dalam menurunkan IMT sehingga perlu memberikan intervensi nyata yang mempunyai manfaat langsung dalam menurunkan berat badan.

\section{SIMPULAN DAN SARAN}

Pendidikan kesehatan tentang obesitas menggunakan media SMS dan booklet memberikan pengaruh dalam meningkatkan pengetahuan pada remaja yang mengalami overweight dan obese. Dengan demikian, media SMS dan booklet bisa digunakan untuk meningkatkan pengetahuan, tetapi sebaiknya frekuensi pemberian booklet dilakukan lebih dari sekali misalnya sebanyak 3 kali secara bertahap selama dilakukan penelitian agar memberikan pengaruh yang lebih maksimal. Selain menggunakan media SMS dan booklet, penelitian selanjutnya bisa menggunakan media audio visual dan pemanfaatan smartphone melalui media sosial misalnya facebook, blackberry messenger (BBM), whatsapp, line, instagram, dan lain sebagainya agar pendidikan kesehatan yang diberikan menjadi lebih menarik.

\section{RUJUKAN}

1. Popkin BM. The nutrition transition and obesity in the developing world. J Nutr 2001;131(3):871S-873S.

2. Ogden CL, Carroll MD, Curtin LR, McDowell MA, Tabak CJ, Flegal KM. Prevalence of overweight and obesity in the United States, 1999-2004. JAMA 2006;295(13):154955 .
3. WHO. Obesity: Preventing and managing the global epidemic report of WHO consultation. Geneva: WHO; 2000.

4. Kemenkes RI. Laporan hasil Riset Kesehatan Dasar (Riskesdas) Indonesia tahun 2013. Jakarta: Kemenkes RI; 2013.

5. Mahdiah, Hadi H, Susetyowati. (2004). Prevalensi obesitas dan hubungan konsumsi fast food dengan kejadian obesitas pada remaja SLTP kota dan desa di Daerah Istimewa Yogyakarta. Jurnal Gizi Klinik Indonesia 2004;1(2):69-77.

6. Sukaton U. Kelainan metabolik pada obesitas. Majalah Dokter Keluarga 1990;9(10):14.

7. Saragih JES. Promosi kesehatan untuk penanggulangan overweight dan obesitas pada mahasiswi akademi kebidanan [Tesis]. Yogyakarta: Universitas Gadjah Mada; 2007.

8. Joo NS, Kim BT. Mobile phone short message service messaging for behaviour modification in a communitybased weight control programme in Korea. J Telemed Telecare 2007;13(8):416-20.

9. Huriyati E, Hadi H, Julia M. Aktivitas fisik pada remaja SLTP Kota Yogyakarta dan Kabupaten Bantul serta hubungannya dengan kejadian obesitas. Jurnal Gizi Klinik Indonesia 2004;1(2):59-66.

10. Abdullah IR. Pengaruh penyuluhan dengan media audiovisual terhadap tingkat pengetahuan, sikap dan perilaku ibu gizi kurang dan buruk di Kabupaten Kotawaringin Barat Provinsi Kalimantan Tengah [Tesis]. Yogyakarta: Universitas Gadjah Mada; 2007.

11. Triana W. Pendidikan kesehatan melalui metode ceramah dengan modul, dibandingkan metode ceramah tanpa modul untuk meningkatkan pengetahuan dan sikap wanita dalam menghadapi menopause di Kota Yogyakarta [Tesis]. Yogyakarta: Universitas Gadjah Mada; 2002.

12. Murti B. Prinsip dan metode riset epidemiologi. Yogyakarta: Gadjah Mada University Press; 2003.

13. Kusfriyadi MK, Hadi H, Fuad A. Pendidikan gizi dan pesan gizi melalui short message service terhadap pengetahuan, perilaku, dan kepatuhan ibu hamil minum tablet besi. Jurnal Gizi Klinik Indonesia 2012;9(2):87-96.

14. Goodarzi M, Ebrahimzadeh I, Rabi A, Saedipoor B, Jafarabadi MA. Impact of distance education via mobile phone text messaging on knowledge, attitude, practice and self efficacy of patients with type 2 diabetes mellitus in Iran. J Diabetes Metab Disord 2012;11(1):10.

15. Fjeldsoe BS, Marshall AL, Miller YD. Behavior change interventions delivered by mobile telephone short-message service. American Journal of Preventive Medicine 2009;36(2):165-73.

16. Mintarsih. Pendidikan kesehatan menggunakan booklet dan poster dalam meningkatkan pengetahuan dan sikap remaja 
tentang kesehatan reproduksi di Kabupaten Tasikmalaya. [Tesis]. Yogyakarta: Universitas Gadjah Mada; 2007.

17. Andriani R, Effendy R, Nurhesti P. Perbedaan Tingkat pengetahuan perawat pre dan post pemberian booklet diagnosa keperawatan dan masalah kolaboratif pada pasien stroke. Jurnal Ilmu Keperawatan 2009;4(3).

18. Arsyad A. Media pembelajaran. (A. Rahman, Ed.). Jakarta: PT Raja Grafindo Persada; 2011.

19. Sulastri N, Effendy C, Haryani. Pengaruh pendidikan kesehatan terhadap pengetahuan dan keterlibatan keluarga dalam pencegahan dekubitus pada pasien tirah baring. Jurnal Ilmu Keperawatan 2008;3(3):193-201.

20. Muhammad. Efektivitas layanan pesan pendek dan media leaflet dalam promosi kesehatan tentang kesiapsiagaan bencana bagi pelajar sekolah menengah pertama di Kota Banda Aceh. [Tesis]. Yogyakarta: Universitas Gadjah Mada; 2011.

21. Nelson JA, Carpenter K, Chiasson MA. Diet, activity, and overweight among preschool-age children enrolled in the Special Supplemental Nutrition Program for
Women, Infants, and Children (WIC). Prev Chronic Dis 2006;3(2):A49.

22. Siswadi Y, Dayrit M, Baradero M. Konseling dalam keperawatan. Jakarta: EGC; 2006

23. De Bourdeaudhuij I, Lefevre J, Deforche B, Wijndaele K, Matton L, Philippaerts R. Physical activity and psychosocial correlates in normal weight and overweight 11 to 19 year olds. Obes Res 2005;13(6):1097-105.

24. Berkey CS, Rockett HR, Gillman MW, Colditz GA. OneYear changes in activity and in inactivity among 10- to 15-year-old boys and girls: relationship to change in body mass index. Pediatrics 2003;111(4):836-43.

25. Boutcher SH. High-intensity intermittent exersice and fat loss. J Obes 2011;2011:868305.

26. Kurniasih D, Hilmansyah H, Astuti MP, Imam S. Sehat dan bugar berkat gizi seimbang. Jakarta: PT Gramedia; 2010.

27. Lowry R, Lee SM, Fulton JE, Demissie Z, Kann L. Obesity and other correlates of physical activity and sedentary behavior among US high scool students. J Obes 2013;2013:276318. 